\title{
CBP in the Nucleus Accumbens Regulates Cocaine-Induced Histone Acetylation and Is Critical for Cocaine-Associated Behaviors
}

\author{
Melissa Malvaez, ${ }^{1}$ Emanuela Mhillaj, ${ }^{2}$ Dina P. Matheos, ${ }^{1}$ Maura Palmery, ${ }^{2}$ and Marcelo A. Wood ${ }^{1}$ \\ ${ }^{1}$ University of California, Irvine; Department of Neurobiology and Behavior; Center for the Neurobiology of Learning and Memory; Irvine, California 92697- \\ 3800, and ${ }^{2}$ Department of Physiology and Pharmacology, Sapienza University of Rome, 00185 Rome, Italy
}

Cocaine exposure triggers molecular events that lead to long-lasting changes in brain structure and function. These changes can lead to the development of persistent and robust behavioral adaptations that characterize addiction. Recent evidence suggests the regulation of transcription via chromatin modification, such as histone acetylation, has an important role in the development of addictive behavior. Histone acetylation is regulated by histone acetyltransferases (HATs), which acetylate histones and promote transcription, and histone deacetylases (HDACs), which remove acetyl groups and silence transcription. Studies have demonstrated that HDACs may negatively regulate cocaine-induced behaviors, but very little is known about the role of specific HATs in long-lasting drug-induced plasticity. The histone acetyltransferase CREB-binding protein (CBP) mediates transcriptional activation by recruiting basal transcription machinery and acetylating histones. CBP is a critically important chromatin-modifying enzyme involved in regulating gene expression required for long-term plasticity and memory. However, the role of CBP in cocaine-induced behaviors remains largely unknown. We examined the role of CBP in drug-induced plasticity using CBP-FLOX genetically modified mice in combination with adeno-associated virus expressing Cre-recombinase to generate focal homozygous deletions of $C b p$ in the nucleus accumbens (NAc). A complete loss of CBP in NAc neurons results in decreased histone acetylation and significantly altered c-fos expression in response to cocaine. Furthermore, the deletion of CBP in the NAc correlates with significant impairments in cocaine sensitivity and context-cocaine associated memory. This is the first study to demonstrate a definitive role for CBP in modulating gene expression that may subserve drug-seeking behaviors.

\section{Introduction}

Evidence shows that cocaine exposure triggers altered gene expression within the nucleus accumbens, contributing to the development and persistence of drug addiction (Nestler et al., 1993; Hope et al., 1994; Hyman and Malenka, 2001; Nestler, 2001; Hyman et al., 2006; McClung and Nestler, 2008). Chromatin modification is emerging as a major molecular mechanism involved in the regulation of gene expression critical for long-lasting forms of synaptic plasticity, memory processes, and drug-induced neural and behavioral changes (McClung and Nestler, 2008; Renthal and Nestler, 2008). Cocaine induces specific chromatin modifications, such as histone acetylation, that modulate histone-DNA interactions and the recruitment of transcriptional regulatory complexes, leading to changes in transcription that may underlie

\footnotetext{
Received June 1, 2011; revised Sept. 16, 2011; accepted Sept. 22, 2011.

Author contributions: M.M., D.P.M., and M.A.W. designed research; M.M., E.M., and D.P.M. performed research; M.P. contributed unpublished reagents/analytic tools; M.M., E.M., and D.P.M. analyzed data; M.M. wrote the paper.

This work was supported by National Institute of Mental Health Grant R01MH081004 (to M.A.W.), National Institute on Drug Abuse Grant R01DA025922 (to M.A.W.), and National Research Service Award Predoctoral Fellowship F31DA29368 (to M.M). We thank Nguyen Vo and Luis Martinez for their technical assistance.

The authors declare no competing financial interests.

Correspondence should be addressed to Marcelo A. Wood, University of California, Irvine, Department of Neurobiology and Behavior, Center for the Neurobiology of Learning and Memory, 106 Bonney Research Laboratory, Irvine, CA 92697-3800. E-mail: mwood@uci.edu.

DOI:10.1523/JNEUROSCI.2747-11.2011

Copyright $\odot 2011$ the authors $\quad 0270-6474 / 11 / 3116941-08 \$ 15.00 / 0$
}

aspects of cocaine addiction (Kumar et al., 2005; Renthal et al., 2007, 2008; Winstanley et al., 2009).

Although changes in histone acetylation in response to cocaine have been documented, relatively little is known about the specific histone acetylation enzymes involved in cocaine-induced plasticity. The enzymes that regulate levels of histone acetylation are histone acetyltransferases (HATs) and histone deacetylases (HDACs), which generally promote or silence gene expression, respectively (Kouzarides, 2007). Numerous studies have shown that manipulation of HDACs in the nucleus accumbens alters drug-induced plasticity and behavior (Kumar et al., 2005; Kalda et al., 2007; Renthal et al., 2007; Pandey et al., 2008; Romieu et al., 2008; Schroeder et al., 2008; Shen et al., 2008; Sun et al., 2008). Conversely, an understanding of the role of HATs in the nucleus accumbens, a key component of the brain's reward circuitry (Di Chiara and Imperato, 1988; Self and Nestler, 1995; Wise, 1996; Hyman et al., 2006), is lacking. CREB-binding protein (CBP) is one of the best studied HATs that has been shown to regulate transcription during memory and synaptic plasticity (Barrett and Wood, 2008). However, the role of CBP in specific brain regions involved in cocaine plasticity (i.e., nucleus accumbens) cannot be determined with the $C b p$ genetically modified mouse models available, because they are not designed to target a single brain region.

To address these issues and examine the specific role of CBP in cocaine-induced plasticity within the nucleus accumbens, we 
used $C b p^{\text {flox/flox }}$ mice carrying loxP sites flanking exon 9 of $C b p$ (Kang-Decker et al., 2004) in combination with an adenoassociated, virus-expressing Cre recombinase (AAV2/1-Cre) to knock-out $C b p$ in a focal manner. We found that cocaineinduced increases in histone acetylation of specific residues are blunted in neurons lacking CBP. Second, we found that cocaineinduced c-fos expression is significantly altered in the absence of CBP. Furthermore, cocaine sensitivity and reward are impaired in mice that have a focal knock-out CBP in the nucleus accumbens. Our findings indicate that the histone-modifying enzyme CBP has a critical role within the nucleus accumbens in the regulation of molecular adaptations that may characterize aspects of drug-seeking behavior.

\section{Materials and Methods}

Subjects and surgical procedures. CBP conditional knock-out mice $\left(C b p^{\text {flox/flox }}\right)$ were generated as described in detail by Kang-Decker et al. (2004) and are maintained on a C57BL/6 background. In the presence of Cre recombinase, the sequence between the loxP sites can be deleted, producing a truncated, nonfunctional CBP (Barrett et al., 2011; KangDecker et al., 2004). To generate a focal deletion, 2 weeks before behavioral procedures mice were infused with an adeno-associated virus expressing Cre recombinase (AAV2/1-Cre; Penn Vector Core, University of Pennsylvania, Philadelphia, PA) as described previously (Barrett et al., 2011; McQuown et al., 2011). AAV2/1-Cre $(0.25 \mu \mathrm{l})$ was infused at a rate of $6 \mu \mathrm{l} / \mathrm{h}$ via an infusion needle positioned in the nucleus accumbens [anteroposterior (AP), $-1.3 \mathrm{~mm}$; mediolateral, $\pm 1.1 \mathrm{~mm}$; dorsoventral, $-4.5 \mathrm{~mm}$ ]. For all experiments, mice of either sex were $8-12$ weeks old and had access to food and water ad libitum in their home cages. Lights were maintained on a $12 \mathrm{~h}$ light/dark cycle, with all behavioral testing performed during the light portion of the cycle. All experiments were conducted according to National Institutes of Health Guidelines for Animal Care and Use and were approved by the Institutional Animal Care and Use Committee of the University of California, Irvine, CA.

Immunofluorescence. One hour following the last saline or cocaine injection, mice were euthanized by cervical dislocation and their brains removed and frozen at $-20^{\circ} \mathrm{C}$ by immersion in isopentane. Coronal sections were cut at a thickness of $20 \mu \mathrm{m}$ on a cryostat at the level corresponding to the nucleus accumbens (AP, $+1.4 \mathrm{~mm}$ to +0.6 $\mathrm{mm}$ ), thaw-mounted on glass slides, and stored at $-20^{\circ} \mathrm{C}$ until used for immunofluorescence. Slides were fixed with $4 \%$ paraformaldehyde for $10 \mathrm{~min}$ and immunofluorescence was performed as described previously (Barrett et al., 2011; McQuown et al., 2011; Vecsey et al., 2007; Malvaez et al., 2010). Briefly, slides were blocked for $1 \mathrm{~h}$ at room temperature in $8 \%$ normal goat serum (NGS, Jackson ImmunoResearch Laboratories) with $0.3 \%$ Triton X-100 in PBS and then incubated overnight at $4^{\circ} \mathrm{C}$ in $2 \%$ NGS and $0.3 \%$ Triton X-100 in PBS with primary antibody The slides were then incubated for $2 \mathrm{~h}$ at room temperature with goat anti-rabbit IgG-FITC (1:1000, Millipore), and slides were coverslipped using ProLong Gold anti-fade reagent with DAPI (Invitrogen). Primary antibodies used were CBP (C-20, 1:1000; Santa Cruz Biotechnology), acetylhistone-H3K14 (1:1000; Millipore), acetyl-histone-H2BK12 (1:500, Abcam), acetyl-histone-H4K12 (1:500; Millipore), and dimethyl-histoneH3K9 (1:500; Millipore).

All images were acquired using an Olympus (BX51) microscope using a $4 \times$ or $20 \times$ objective CCD camera (QImaging) and QCapture Pro 6.0 software (QImaging), combined with ImageJ software (NIH). A single optimized acquisition exposure time was used for all images acquired from a particular slide with all treatment groups represented. Immunolabeling was quantified using ImageJ software by measuring the optical density in the area corresponding to the nucleus accumbens from comparable $20 \times$ images. For each animal, the average of four sections was calculated to give a mean optical density for an animal.

Quantitative real-time RT-PCR. Quantitative real-time RT-PCR was performed to examine c-fos expression. Tissue was collected by taking 1 $\mathrm{mm}^{2}$ punches from nucleus accumbens sections in the area of the focal deletion in $C b p^{\text {flox/flox }}$ mice as confirmed by immunofluorescence for
$\mathrm{CBP}$ and equivalent regions in $\mathrm{Cbp}{ }^{+/+}$mice. RNA was isolated using RNeasy Minikit (Qiagen). cDNA was made from 75 ng of total RNA using the Transcriptor First Strand cDNA Synthesis kit (Roche Applied Science). The following primers were derived from the Roche Universal ProbeLibrary: c-Fos left primer, 5' -ggggcaaagtagagcagcta-3'; c-Fos right primer, $5^{\prime}$-agctccctcctccgattc- $3^{\prime}$; probe, atggctgc (c-Fos probe is conjugated to the dye FAM); glyceraldehyde-3-phosphate dehydrogenase (GAPDH) left primer, 5' -atggtgaaggtcggtgtga- $3^{\prime}$; GAPDH right primer, $5^{\prime}$-aatctccactttgccactgc- $3^{\prime}$; probe, tggcggtattgg (GAPDH probe is conjugated to LightCycler Yellow5 55). The nonoverlapping dyes and quencher on the reference gene allow for multiplexing in the Roche LightCycle 480 II machine (Roche Applied Science). All values were normalized to GAPDH expression levels. Analysis and statistics were performed using the Roche proprietary algorithms and REST 2009 software based on the Pfaffl method (Pfaffl, 2001; Pfaffl et al., 2002).

Chromatin immunoprecipitation. Tissue was collected from wild-type mice $1 \mathrm{~h}$ following the last injection (saline or cocaine). For each sample, bilateral ventral striatum (AP, $+1.4 \mathrm{~mm}$ to $+0.6 \mathrm{~mm}$ ) was isolated from two $1 \mathrm{~mm}$ sections. Chromatin immunoprecipitation (ChIP) was performed based on the protocol from the Millipore ChIP kit. Briefly, tissue was cross-linked using 1\% formaldehyde (Sigma), lysed and sonicated, and chromatin was immunoprecipitated overnight with anti-acetylated H3 (positive control; Millipore), anti-CBP (Abcam), or nonimmune rabbit IgG (negative control; Millipore). The immunoprecipitation was collected using magnetic Protein A beads (Millipore). After washing, chromatin was eluted from the beads and reverse cross-linked in the presence of proteinase K. DNA was purified and then quantified using quantitative real-time PCR. c-fos promoter enrichment in ChIP samples was measured by quantitative PCR using the Roche 480 LightCycler and SYBR Green. Primer sequences used to amplify the promoter region were designed by the Primer 3 program $\left(5^{\prime}\right.$-tacgaccccttcaggcatac- $3^{\prime}$ and $5^{\prime}$ gttttaaaggacggcagcac- $3^{\prime}$ ). Five microliters of input, ChIP, or IgG sample were used in each reaction in duplicate for three biological samples in each condition. Percentage input was calculated for both the ChIP and IgG samples and then fold enrichment was calculated as a ratio of the ChIP to IgG. An in-plate standard curve determined amplification efficiency $(\mathrm{AE})$, and the 100 fold dilution factor for the input was included. The equa-

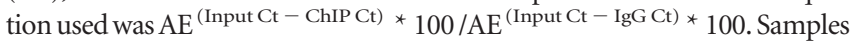
were then normalized to the saline condition.

Locomotor activity. Before any behavioral procedure, mice of either sex were handled for 1-2 min for $3 \mathrm{~d}$ and habituated to the activity apparatus (Plexiglas open field with sawdust bedding; base, $16 \mathrm{~cm} \times 32 \mathrm{~cm}$ ) for 30 $\mathrm{min} /$ day for 2 consecutive days. $\mathrm{Cbp}{ }^{+/+}$and $\mathrm{Cb} p^{\text {flox/flox }}$ mice were randomized into three different treatment groups (Control, Acute, and Chronic), and locomotor activity was monitored for $30 \mathrm{~min}$ after an intraperitoneal injection of cocaine- $\mathrm{HCl}(10 \mathrm{mg} / \mathrm{kg}$; Sigma $)$ or vehicle ( $0.9 \%$ saline). The Control group received saline injections on days 1-5. The Acute group received saline injections on days 1-4 and a single cocaine injection on day 5 . The Chronic group received cocaine injections on days 1-5. Locomotor activity (total distance traveled) was recorded each day with a video camera mounted above the activity apparatus and tracked automatically from MPEG videos using EthoVision 3.1 software (Noldus Information Technology; see (Pham et al., 2009).

Conditioned place preference. Place conditioning was performed as described previously (Malvaez et al., 2010). Briefly, mice of either sex were paired $30 \mathrm{~min} /$ day for 4 days (unbiased paradigm) with alternating injections of cocaine- $\mathrm{HCl}(2.5 \mathrm{mg} / \mathrm{kg}$, i.p.; Sigma) and $0.9 \%$ saline. Fortyeight hours after the last conditioning session, preference (difference in time spent in cocaine-paired compartment versus saline-paired compartment) was assessed (15 min test) in all animals in a drug-free state. Time spent in each chamber of the conditioned place preference apparatus was tracked automatically from MPEG videos as above.

Statistics. Datasets were analyzed by repeated-measures ANOVA, twoway, or one-way ANOVA. Bonferroni post hoc tests were performed when appropriate. Specific comparisons were made using Student's $t$ tests with alpha levels held at 0.05 . 
A
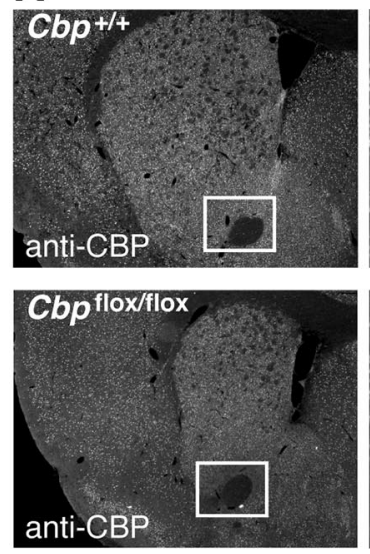
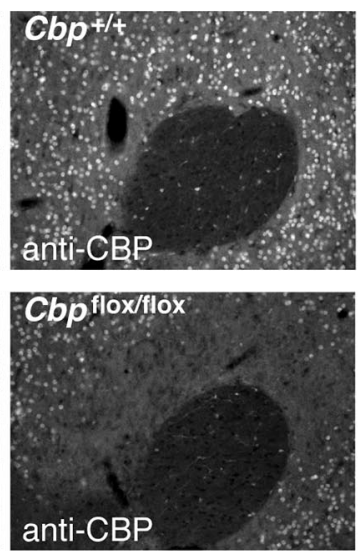

B

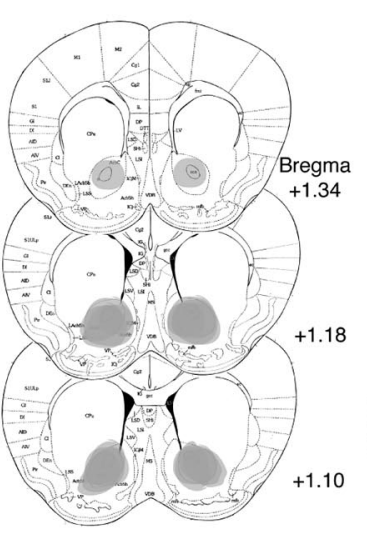

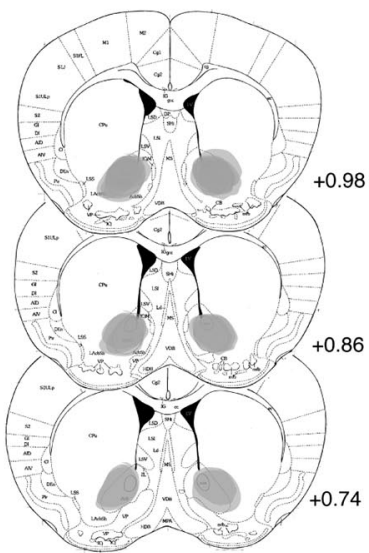

Figure 1. AAV2/1-Cre infusion in C $b p^{\text {flox/flox }}$ mice results in a complete focal deletion of CBP restricted to nucleus accumbens. $A$, Representative images [ $4 \times$ (left) and $20 \times$ (right) magnification of the regions boxed in white] showing CBP immunoreactivity in nucleus accumbens of $A A V 2 / 1-C r e-i n f u s e d ~ C b p p^{+/+}$and $C b p^{\text {flox/flox }}$ mice. CBP labeling is found throughout striatum, except in the AAV2/1-Cre infusion site of $C b p^{\text {flox/flox }}$ mice. B, Deletion of CBP in AAV2/1-Cre infused $C b p{ }^{\text {flox/flox }}$ mice is confined to nucleus accumbens, spreading +1.20 to $+0.70 \mathrm{~mm}$ AP from bregma.

\section{Results}

Generation of focal homozygous $C b p$ deletion in nucleus accumbens

To generate a homozygous deletion of $C b p$, we used mice carrying loxP sites flanking exon 9 of $C b p$ ( $C b p^{\text {flox/flox }}$ mice (KangDecker et al., 2004) in which Cre recombinase excises exon 9 of Cbp. Cre recombinase was delivered via adeno-associated virus (AAV2/1-Cre). Cbp ${ }^{\text {flox/flox }}$ and $C b p^{+/+}$mice received bilateral nucleus accumbens infusions of AAV2/1-Cre $(0.25 \mu \mathrm{l} / \mathrm{side})$ serotype $2 / 1$. This serotype has been shown to efficiently transduce neurons at a higher efficiency than other cell types (Burger et al., 2004). Two weeks after AAV2/1-Cre infusion, a time at which a floxed gene is optimally deleted (Scammell et al., 2003; Barrett et al., 2011; McQuown et al., 2011), we observed a complete deletion of CBP in $C b p^{\text {flox/flox }}$ mice as demonstrated by loss of CBP immunoreactivity in the nucleus accumbens (Fig. $1 A$ and data not shown: $\mathrm{Cbp}^{+/+}, 100.0 \pm 2.93, n=3$ vs $C b p^{\text {flox/llox }}, 3.27 \pm$ $0.54, n=3$; Student's $t$ test, $t_{4}=32.47, p<0.0001$ ). The deletion of $\mathrm{CBP}$ was restricted to the nucleus accumbens, spanning +1.20 to $+0.70 \mathrm{~mm}$ AP from bregma (Fig. $1 \mathrm{~B}$ ). The viral infusion does not alter neuronal morphology, induce cell death, or impair basal synaptic transmission (data not shown; Scammell et al., 2003; Barrett et al., 2011; McQuown et al., 2011). Furthermore, there is no difference in CBP protein or mRNA expression in $C b p^{\text {flox/flox }}$ mice not exposed to AAV2/1-Cre, and there is no difference in long-term memory in $C b p^{\text {flox/flox }}$ mice as compared to wild-type littermates, demonstrating that loxP sites in $C b p^{\text {flox/flox }}$ mice have no effect by themselves on CBP expression or behavior of the animal (Barrett et al., 2011).

\section{CBP regulates the histone acetylation induced by cocaine in} the nucleus accumbens

Cocaine treatment has been shown to induce histone acetylation in the nucleus accumbens (Kumar et al., 2005; Levine et al., 2005). To determine whether cocaine-induced histone acetylation is regulated by CBP in the nucleus accumbens, we treated $C b p^{\text {flox/flox }}$ and $\mathrm{Cbp}^{+/+}$mice with saline or acute or chronic cocaine. Using immunofluorescence, we examined histone acetylation in $C b p^{\text {flox/flox }}$ and $C b p^{+/+}$mice $1 \mathrm{~h}$ after the last cocaine injection. Acetylation of lysine 14 on H3 (H3K14ac), a known target of CBP (Barrett et al., 2011; Kouzarides, 2007), was significantly increased in the nucleus accumbens of $C b p^{+/+}$mice $1 \mathrm{~h}$
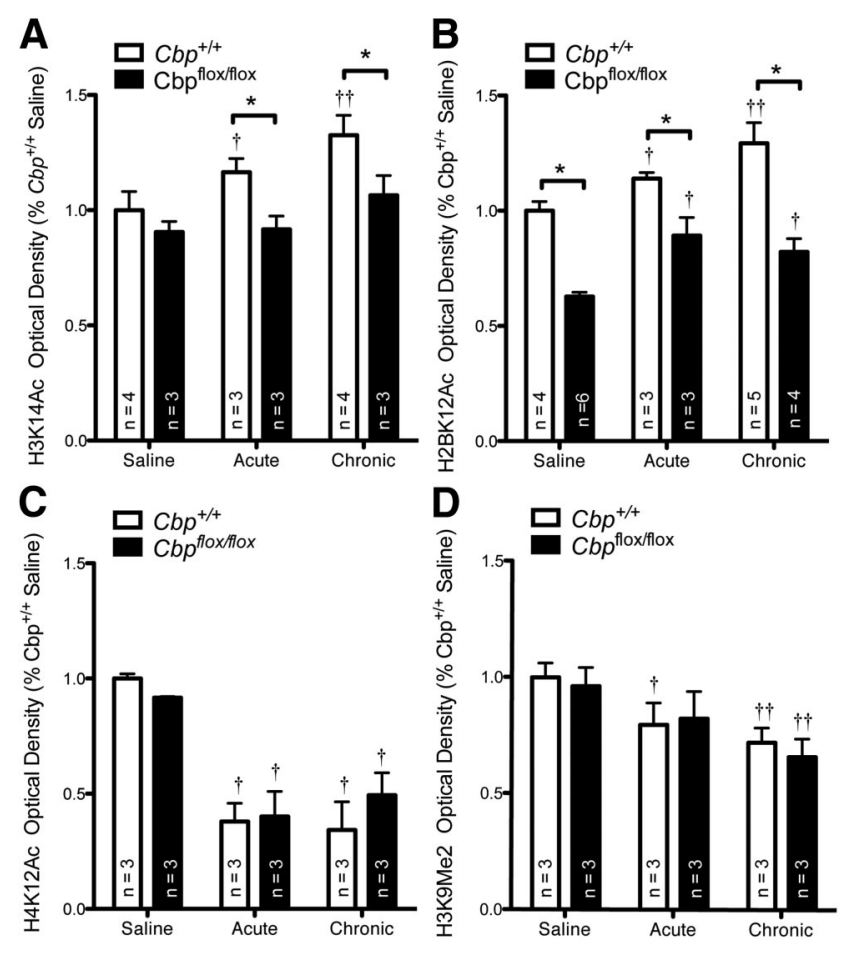

Figure 2. Homozygous deletion of C $b p$ disrupts histone acetylation induced in the nucleus accumbens by cocaine treatment. Nucleus accumbens sections from $\mathrm{Cbp}^{+/+}$and $\mathrm{Cbp}$ flox/flox mice infused with AAV2/1-Cre were immunolabeled, and optical density of $20 \times$ magnification images of infusion site (CBP deletion confirmed by immunolabeling in $\mathrm{Cbp}^{+/+}$and $\mathrm{Cbp}$ flox/flox mice) was quantified. $\boldsymbol{A}$, Acetylation of $\mathrm{H} 3 \mathrm{~K} 14$ increases with acute cocaine and increases further with chronic cocaine in $C b p^{+/+}$mice, but H3K14Ac does not increase in $C b p^{\text {flox/flox }}$ mice in response to cocaine. $\boldsymbol{B}$, Acetylation of $\mathrm{H} 2 \mathrm{BK} 12$ increases with acute and chronic cocaine but is significantly reduced in $C b p^{\text {flox/flox }}$ mice. $\boldsymbol{C}$, Acetylation of H4K12 is reduced with acute and chronic cocaine treatment but is not different between $\mathrm{Cbp}^{+/+}$and $C b p^{\text {flox/flox }}$ mice. D, Dimethylation of $\mathrm{H} 3 \mathrm{~K} 9$ is reduced by acute cocaine and further reduced with chronic treatment in both $\mathrm{Cbp}^{+/+}$and $C b p^{\text {flox/flox }}$ mice. ${ }^{\dagger}$ Significantly different from saline; ${ }^{*}$ significantly different from $C b p^{+/+}$mice; $p<0.05$.

following acute and chronic cocaine treatment (Fig. 2A; ANOVA, significant effect of drug treatment, $F_{(2,14)}=18.51, p<$ 0.0001 ; Bonferroni post hoc, Cbp ${ }^{+++}$acute vs $C b p^{+/+}$saline, $p<$ $0.05, \mathrm{Cbp}^{+/+}$chronic vs $C b p^{+/+}$saline, $p<0.001 ; C b p^{+/+}$: saline $n=4$, acute $n=3$, chronic $n=4$ ). We also found that the 
elevated acetylation of $\mathrm{H} 3 \mathrm{~K} 14$ was sustained in $\mathrm{Cbp}{ }^{+/+}$mice $24 \mathrm{~h}$ after the last cocaine injection (data not shown). Interestingly, H3K14Ac was not different between $C b p^{\text {flox/flox }}$ and $C b p^{+/+}$mice following saline; however acetylation of $\mathrm{H} 3 \mathrm{~K} 14$ was significantly blunted in response to both acute and chronic cocaine in $C b p^{\text {flox/flox }}$ mice (ANOVA, significant effect of genotype, $F_{(1,14)}=37.44, p<$ 0.0001; Bonferroni post hoc, $C b p^{+/+}$saline vs $C b p^{\text {flox/flox }}$ saline, ns, $C b p^{+/+}$acute vs $C b p^{\text {flox/flox }}$ acute, $p<0.01, C b p^{+/+}$chronic vs $C b p^{\text {flox/flox }}$ chronic, $p<0.01 ; C b p^{\text {flox/flox }}$ : saline $n=3$, acute $n=3$, chronic $n=3)$. H2BK12Ac, a known target of CBP and a site whose acetylation is severely affected by CBP deletion (Barrett et al., 2011), was significantly increased by acute and chronic cocaine in $\mathrm{Cbp}^{+/+}$mice (Fig. $2 \mathrm{~B}$; ANOVA, significant effect of drug treatment, $F_{(2,14)}=18.51, p<0.0001$; Bonferroni post hoc, $C b p^{+/+}$acute vs $C b p^{+/+}$saline, $p<0.01, C b p^{+/+}$chronic vs $C b p^{+/+}$saline, $p<0.001 ; C b p^{+/+}:$saline $n=4$, acute $n=3$, chronic $n=5)$. In $C b p^{\text {flox/flox }}$ mice, H2BK12Ac was reduced across all treatments, including saline treatment (ANOVA, significant effect of genotype, $F_{(1,19)}=236.1, p<0.0001$; Bonferroni post hoc, $C b p^{+/+}$saline vs $C b p^{\text {flox/flox }}$ saline, $p<0.001$, $C b p^{+/+}$acute vs $C b p^{\text {flox/flox }}$ acute, $p<0.001, C b p^{+/+}$chronic vs $C b p^{\text {flox/flox }}$ chronic, $p<0.001 ; C b p^{\text {flox/flox }}$ : saline $n=6$, acute $n=$ 3 , chronic $n=4)$. Acetylation on lysine 12 on histone $\mathrm{H} 4$ (H4K12Ac) is not known to be a target of CBP (Kouzarides, 2007), and was not different between $C b p^{+/+}$and $C b p^{\text {flox/flox }}$ mice (Fig. 2C; ANOVA, no effect of genotype, $F_{(1,12)}=0.572, p=$ $n s)$. However, there was a significant decrease in H4K12Ac in both $\mathrm{Cbp} \mathrm{p}^{+/+}$and $\mathrm{Cbp} p^{\text {flox/flox }}$ mice following either acute or chronic cocaine administration (ANOVA, significant effect of treatment, $F_{(2,12)}=86.13, p<0.0001$; Bonferroni post hoc, $C b p^{+/+}$acute vs $C b p^{+/+}$saline, $p<0.001, C b p^{+/+}$chronic vs $C b p^{+/+}$saline, $p<0.001 ; C b p^{+/+}:$saline $n=3$, acute $n=3$, chronic $n=3 ; C b p^{\text {flox/flox }}$ acute vs $C b p^{\text {flox/flox }}$ saline, $p<0.001$, $C b p^{\text {flox/flox }}$ chronic vs $C b p^{\text {flox/flox }}$ saline, $p<0.001 ; C b p^{\text {flox/flox }}$ : saline $n=3$, acute $n=3$, chronic $n=3)$. We also examined methylation of histone $\mathrm{H} 3$ lysine 9 ( $\mathrm{H} 3 \mathrm{~K} 9 \mathrm{Me} 2)$, a site known to cross talk with H3K14Ac (Kouzarides, 2007) and regulated by cocaine (Maze et al., 2010) but not directly regulated by CBP. In $\mathrm{Cbp} \mathrm{p}^{+/+}$mice, acute cocaine treatment lead to reduced H3K9Me2 and chronic cocaine treatment further reduced H3K9Me2 (Fig. $2 D$; ANOVA, significant effect of treatment, $F_{(2,12)}=18.33, p<$ 0.001; Bonferroni post hoc, $C b p^{+1+}$ acute vs $C b p^{+++}$saline, $p<$ $0.05, C b p^{+/+}$chronic vs $C b p^{+/+}$saline, $p<0.01 ; C b p^{+/+}$: saline $n=3$, acute $n=3)$. No overall difference between genotypes was found (no effect of genotype, $F_{(1,12)}=0.39, p=n s$ ); however, in $C b p^{\text {flox/flox }}$ mice only chronic cocaine treatment was able to reduce methylation of $\mathrm{H} 3 \mathrm{~K} 9\left(C b p^{\text {flox/flox }}\right.$ acute vs $C b p^{\text {flox/flox }}$ saline, $p=\mathrm{ns}, C b p^{\text {flox/flox }}$ chronic vs $C b p^{\text {flox/flox }}$ saline, $p<$ $0.001 ; C b p^{\text {flox/flox }}$ : saline $n=3$, acute $n=3$, chronic $n=3$ ).

We found wild-type expression of $C b p$ is not regulated by cocaine $\left(F_{(2,12)}=0.71, p=0.51 ; C b p^{+/+}:\right.$saline $1.00 \pm 0.04, n=$ 5 , acute $0.97 \pm 0.03, n=4$, chronic $0.99 \pm 0.03, n=6$; data not shown), indicating the effect cocaine treatment has on histone acetylation is dependent on activity of CBP, not its expression. Together with the alterations in histone modifications, these results indicate CBP activity is critical in regulating a specific histone modification pattern in response to cocaine in the nucleus accumbens.

\section{$\mathrm{CBP}$ regulates expression of $\mathrm{c}-\mathrm{fos}$}

Acetylation of histones is a key mechanism in transcriptional regulation (Ogryzko et al., 1996; Kouzarides, 2007) and is also involved in c-fos activation in response to cocaine (Kumar et al.,
A
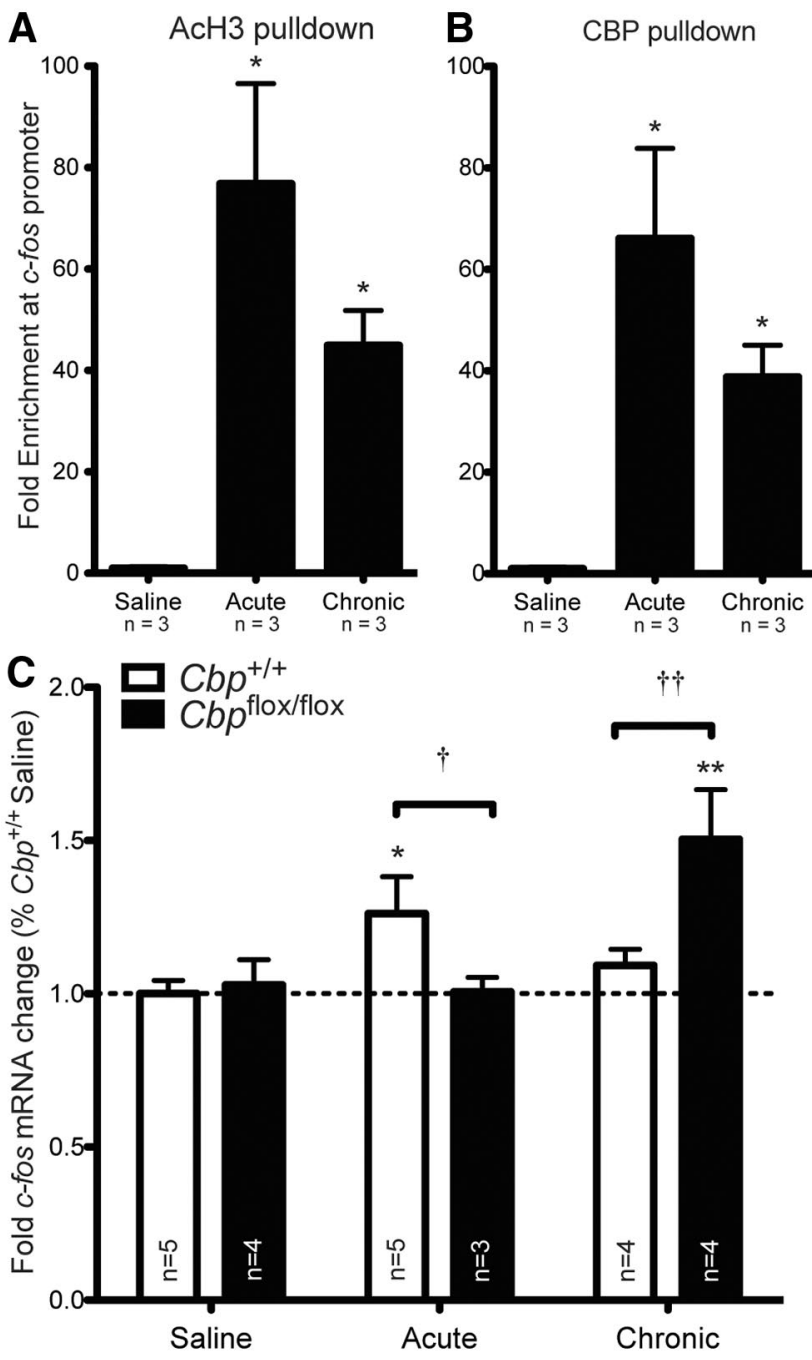

Figure 3. Cocaine-induced c-fos expression is regulated by CBP and altered in response to cocaine in the absence of CBP. ChIP was performed on ventral striata of saline and cocainetreated wild-type mice with anti-acetylated $\mathrm{H} 3(\mathrm{AcH} 3)(\boldsymbol{A})$ or anti-CBP $(\boldsymbol{B})$ antibodies and levels of c-fos promoter in the IPs were measured by quantitative PCR. A, Acetylation on the c-fos promoter increases $1 \mathrm{~h}$ after acute and chronic cocaine treatment in wild-type mice, with a more robust effect by acute treatment. $\boldsymbol{B}$, Cocaine exposure leads to the recruitment of CBP to the c-fos promoter, with a more robust effect by acute cocaine. $\boldsymbol{C}$, Acute cocaine induces c-fos expression and chronic cocaine desensitizes c-fos expression in $\mathrm{Cbp}^{+/+}$mice. In Cbp flox/flox mice, basal c-fos expression is unaltered, but acute cocaine fails to induce c-fos expression. Furthermore, c-fos expression is deregulated with chronic cocaine in $C b p^{\text {flox/flox }}$ mice. *Significantly different from saline, $p<0.05 ;{ }^{\dagger}$ significantly different between genotype, $p<0.05$.

2005). We examined acetylation at the c-fos promoter using chromatin immunoprecipitation in the ventral striatum of wild-type mice $1 \mathrm{~h}$ following both acute and chronic cocaine treatment. Cocaine treatment significantly induces acetylation of histone $\mathrm{H} 3$ in the ventral striatum. We found acute cocaine induces a more robust effect on acetylation of histone $\mathrm{H} 3$ than chronic cocaine (Fig. 3A; one-way ANOVA, $F_{(2,6)}=9.94, p<0.01$; Bonferroni post hoc, acute vs saline, $t=4.44, p<0.05$, chronic vs saline, $t=$ 2.57, $p=$ ns; saline $n=3$, acute $n=3$, chronic $n=3$ ). Next, we examined the interaction of CBP and the c-fos promoter following acute and chronic cocaine. Similar to the effect on acetylation, cocaine treatment significantly increased CBP occupancy at the c-fos promoter, with a more robust increase following acute treatment than chronic treatment (Fig. $3 B$; one-way ANOVA, $F_{(2,6)}=$ 9.05, $p<0.05$; Bonferroni post hoc, acute vs saline, $t=4.24$, 
$p<0.05$, chronic vs saline, $t=2.46, p=$ ns; saline $n=3$, acute $n=3$, chronic $n=3$ ).

The chromatin immunoprecipitation data in Figure 3, $A$ and $B$, suggested that gene expression would be altered in response to cocaine in the nucleus accumbens of $C b p^{\text {flox/flox }}$ mice lacking CBP. To determine whether cocaine-induced gene expression was affected by the CBP deletion, we examined c-fos expression in $C b p^{\text {flox/flox }}$ and $C b p^{+/+}$mice $1 \mathrm{~h}$ following the last cocaine injection (acute or chronic). Tissue was collected by taking $1 \mathrm{~mm}$ punches from the nucleus accumbens in the area of the focal deletion in $C b p^{\text {flox/flox }}$ mice, as confirmed by immunohistochemistry, and the respective area in wild-type littermate controls. We found that c-fos expression in the nucleus accumbens of $\mathrm{Cbp} \mathrm{p}^{+/+}$ mice was induced by acute cocaine and desensitized by chronic cocaine, consistent with previous studies (Hope et al. 1992; Daunais et al., 1993; Fig. 3B; ANOVA, significant effect of treatment, $F_{(2,9)}=9.09, p<0.01$; Bonferroni post hoc, $\mathrm{Cbp}^{+/+}$acute vs $C b p^{+/+}$Saline, $p<0.05, C b p^{+/+}$chronic vs $C b p^{+/+}$saline, $p=$ ns; $C b p^{+/+}$: saline $n=5$, acute $n=3$, chronic $\left.n=4\right)$. Interestingly, acute cocaine failed to induce c-fos expression in $C b p^{\text {flox/flox }}$ mice, but c-fos expression was not desensitized by chronic cocaine in $C b p^{\text {flox/flox }}$ mice (Fig. $3 B$; significant effect of treatment, ANOVA $F_{(2,7)}=18.15, p<0.001$; Bonferroni post hoc, $C b p^{\text {flox/flox }}$ acute vs $C b p^{\text {flox/flox }}$ saline, $p=\mathrm{ns}, C b p^{\text {flox/flox }}$ chronic vs $C b p^{\text {flox/flox }}$ saline, $p<0.05 ; C b p^{\text {flox/flox }}$ : saline $n=4$, acute $n=4$, chronic $n=3$ ).

Together, these results suggest that CBP directly regulates the promoter of c-fos via histone acetylation in response to cocaine in the nucleus accumbens.

\section{Behavioral response to cocaine is regulated by $\mathrm{CBP}$ in} nucleus accumbens

We next investigated the effect of a homozygous $C b p$ deletion on cocaine sensitivity. Previous studies have shown that acetylation of histones and induction of gene expression in the nucleus accumbens correlates with the behavioral response to cocaine (Bibb et al., 2001; McClung and Nestler, 2003; Kumar et al., 2005; Levine et al., 2005; Renthal et al., 2007). To test whether deletion of $C b p$ affects sensitivity to cocaine, $C b p^{\text {flox/flox }}$ and $C b p^{+/+}$mice received bilateral nucleus accumbens infusions of AAV2/1-Cre 2 weeks before acute or chronic cocaine treatment. Importantly, deletion of $C b p$ did not reduce baseline locomotor activity (Fig. $4 A$, days 1-4). However, loss of Cbp impaired the acute response to cocaine (Fig. $4 A$, day 5; significant effect of injection day, $F_{(4,45)}=15.04, p<0.0001$; Bonferroni post hoc, $C b p^{+/+}$day $1-4$

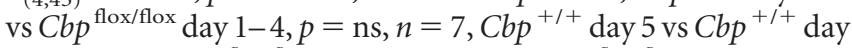
$1, p<0.05, C b p^{\text {flox/flox }}$ day 5 cocaine vs $C b p^{\text {flox/flox }}$ day 1 saline, $\left.p=\mathrm{ns} ; C b p^{+/+} n=7, C b p^{\text {flox/flox }} n=7\right)$. In the chronic treatment following habituation, $C b p^{\text {flox/flox }}$ and $C b p^{+/+}$mice received either saline or cocaine each day for $5 \mathrm{~d}$. In response to chronic cocaine, deletion of $C b p$ resulted in reduced locomotor activity (Fig. $4 B$; significant effect of genotype, $F_{(3,100)}=45.84$, $p<0.0001$; Bonferroni post hoc, Cbp ${ }^{+/+}$chronic day $1-5$ vs $C b p^{\text {flox/flox }}$ chronic day 1-5, $p<0.05, C b p^{+/+} n=10, C b p^{\text {flox } / \text { flox }}$ $n=8$ ). In contrast, $C b p^{+/+}$mice showed the predicted graded increase in locomotor activity in response to repeated cocaine treatment (Fig. $4 B$; significant effect of injection day, $F_{(4,45)}=$ $7.15, p<0.001$; Bonferroni post hoc, $C b p^{+/+}$days 3-5 vs Cbp $p^{+/+}$ day $1, p<0.05, n=10)$. There were no differences between $C b p^{\text {flox/flox }}$ and $C b p^{+/+}$mice treated with chronic saline, indicating normal baseline locomotor activity. Together, these results demonstrate that CBP in the nucleus accumbens is required for both acute and chronic locomotor responses to cocaine.
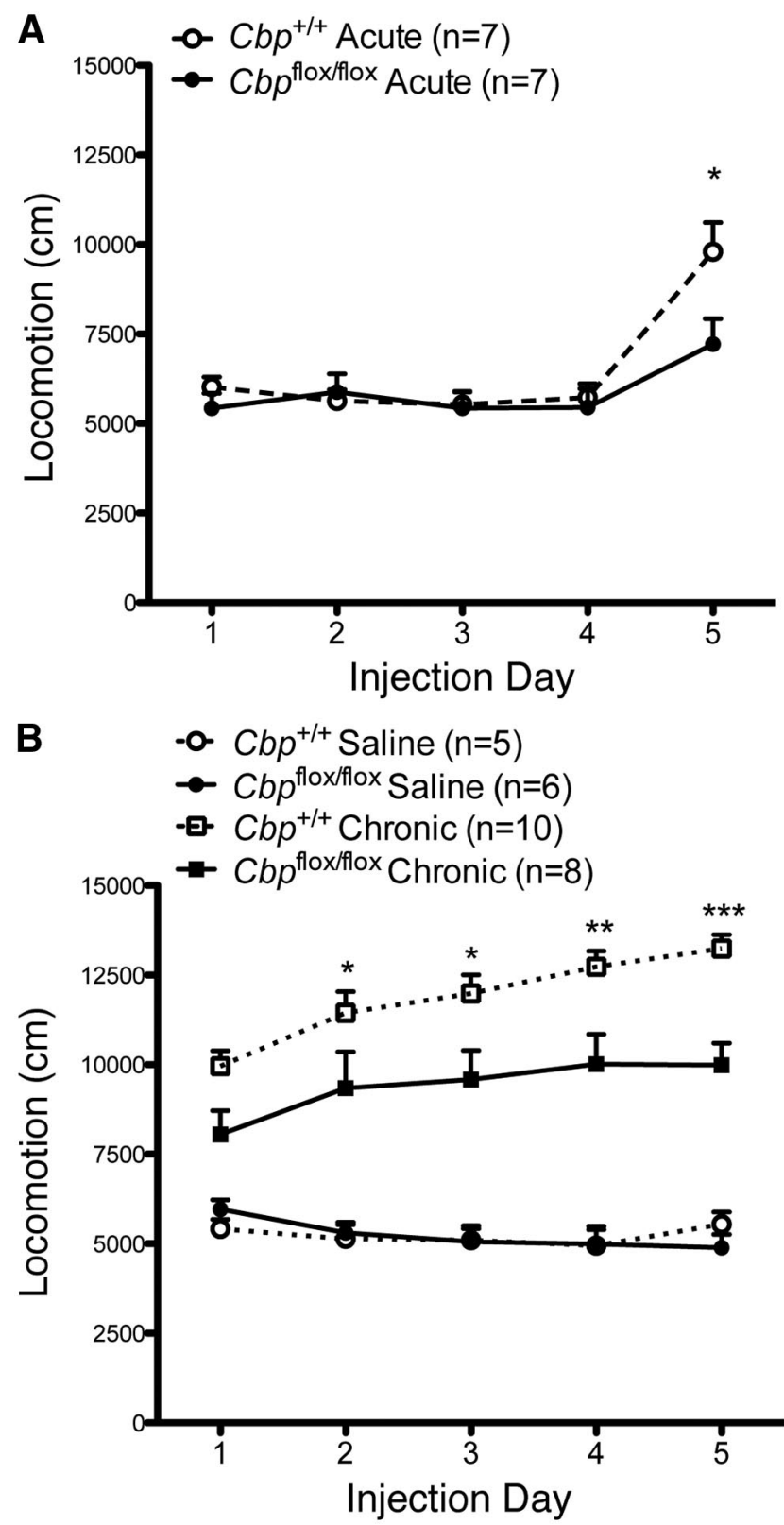

Figure 4. Focal homozygous deletion of CBP in nucleus accumbens disrupts locomotor activating effects of cocaine. $A$, Baseline locomotion in response to saline on (days $1-4$ ) is similar between $\mathrm{Cbp}^{+/+}$and $C b p^{\text {flox/flox }}$ mice, but behavioral response to an acute cocaine injection (day 5) is impaired. $\boldsymbol{B}_{,}\left(b p^{+/+}\right.$mice show increased locomotor activity in response to chronic cocaine (days 1-5) compared to chronic saline (days 1-5) treatment, but $C b p^{\text {flox/flox }}$ mice have reduced sensitivity to chronic cocaine. *Significantly different between genotype, $p<0.05$.

\section{Cocaine reward is regulated by $\mathrm{CBP}$ in the nucleus accumbens}

To further investigate the role of CBP in cocaine reward, we used the conditioned place preference (CPP) paradigm in which animals learn to prefer a context associated with cocaine. A previous study demonstrated that HDAC inhibition during acquisition of cocaine-induced CPP results in significantly enhanced preference for the conditioned context (Kumar et al., 2005), which is presumably due to increased histone acetylation. Thus, we predicted that $C b p^{\text {flox/flox }}$ mice, which have decreased histone acetylation, should exhibit impaired cocaine-induced CPP. Indeed, we observed that a bilateral deletion of $C b p$ in the nucleus accumbens attenuated the rewarding effects of cocaine. $\mathrm{Cbp}{ }^{+/+}$mice 


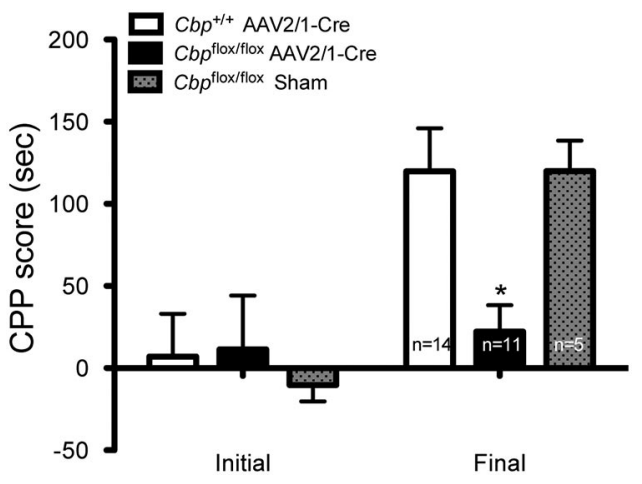

Figure 5. Nucleus accumbens deletion of CBP impairs cocaine reward. No initial preference for either context across all groups. Following conditioned place preference (CPP) training, $C b p^{+/+}$mice infused with AAV2/1-Cre and sham-treated $C b p^{\text {flox/flox }}$ mice exhibited a preference for the cocaine-paired context. However, intranucleus accumbens AAV2/1-Cre-infused $C b p^{\text {flox/flox }}$ mice did not form a preference for the cocaine-paired context. Data presented as difference in time spent in cocaine-paired versus saline-paired context during initial and final preference tests. *Significantly different between groups, $p<0.05$.

that received AAV2/1-Cre and sham treated $C b p^{\text {flox/flox }}$ mice showed a preference for the cocaine-associated context, but $C b p^{\text {flox/flox }}$ mice infused with AAV2/1-Cre were impaired (Fig. 5; significant effect of test, $F_{(1,28)}=17.63, p<0.001$; Bonferroni post hoc, $\mathrm{Cbp}^{+/+}$AAV2/1-Cre final vs $C b p^{\text {flox/flox }}$ AAV2/1-Cre final, $p<0.05, C b p^{+1+}$ AAV2/1-Cre final vs $C b p^{\text {flox/flox }}$ sham final, $p=$ ns, $C b p^{+/+}$AAV2/1-Cre $n=14, C b p^{\text {flox/flox }}$ AAV2/1Cre $n=14, C b p^{\text {flox/flox }}$ sham $\left.n=5\right)$. These findings indicate that $\mathrm{CBP}$ in the nucleus accumbens regulates the behavioral responses to cocaine.

\section{Discussion}

Chromatin modification, such as histone acetylation, has been implicated as a critical mechanism involved in the regulation of gene expression that may underlie long-lasting changes in behavior (McQuown and Wood, 2010; Barrett and Wood, 2008; McClung and Nestler, 2008; Renthal and Nestler, 2008; Malvaez et al., 2010). Currently, very little is known about the specific HATs that regulate histone acetylation implicated in druginduced plasticity within the nucleus accumbens. This study identified $\mathrm{CBP}$ as a critical HAT regulating the actions of cocaine in the nucleus accumbens. We found CBP mediates druginduced cocaine sensitivity and reward by controlling histone acetylation and gene expression.

Studies have shown that acetylation plays a critical role in drug-induced plasticity. Kumar et al. (2005) demonstrated that cocaine treatment induces histone acetylation on promoters of specific genes regulated by cocaine in striatum. Our data indicate that in the nucleus accumbens, CBP is regulating histone acetylation in response to cocaine. We found elevated levels of acetylation on lysine 14 of $\mathrm{H} 3$ following chronic cocaine that were maintained up to $24 \mathrm{~h}$ in wild-type mice. In the absence of CBP, cocaine failed to increase $\mathrm{H} 3 \mathrm{~K} 14$ acetylation, suggesting that $\mathrm{CBP}$ is critical for the induction and maintenance of H3K14 acetylation. Corresponding to this increase in acetylation of $\mathrm{H} 3 \mathrm{~K} 14$, we found a decrease in methylation of $\mathrm{H} 4 \mathrm{~K} 9 \mathrm{Me} 2$ following acute and chronic cocaine treatment in wild-type mice. This is consistent with a recent study showing that chronic cocaine reduces the expression of the histone methyltransferase G9a (Maze et al., 2010). Importantly, we identified novel histone modification sites regulated by cocaine. Acetylation of $\mathrm{H} 2 \mathrm{~B}$ is a feature found on the most active genes (Myers et al., 2003) and has been previ- ously identified as a target of CBP in vitro (Kouzarides, 2007) and in vivo in the hippocampus (Alarcón et al., 2004; Barrett et al., 2011; Valor et al., 2011). Here, we extend H2BK12 as a target of $\mathrm{CBP}$ in the nucleus accumbens, as H2BK12Ac is reduced with saline treatment in mice lacking CBP, and we show that acetylation of this site is regulated by cocaine. Acetylation of $\mathrm{H} 4$ lysine 12 is another modification site that we identified as being regulated by cocaine, however it is not a target of CBP (Fig. 2C; Kleff et al., 1995; Kouzarides, 2007). Generally, histone hyperacetylation is correlated positively with actively transcribed chromatin (Kouzarides, 2007). Acetylation of histone H4 lysine 12, however, has been associated with both upregulated and downregulated gene expression (Dion et al., 2005). Notably, H4K12Ac was dramatically reduced by cocaine exposure. The effect of this histone modification on gene expression and its role in drug-induced plasticity remains to be understood. The fact that CBP expression does not change in response to cocaine indicates that the effects of cocaine on histone acetylation depend on CBP activity. Together, these findings indicate that CBP activity is critical for the acetylation state of specific histone residues, both basal levels and in response to cocaine. Furthermore, these studies begin to elucidate a distinctive pattern of histone modifications regulated by $\mathrm{CBP}$ in response to cocaine.

Acute psychostimulant exposure leads to increases in immediate early gene expression in the striatum (Graybiel et al., 1990; Moratalla et al., 1992; Wang and McGinty, 1995; Miller and Marshall, 2005; Bertran-Gonzalez et al., 2008; Gross et al., 2011) that are partly mediated by activation of the adenylate cyclase/cAMP/ PKA/CREB pathway (Konradi et al., 1994; Carlezon et al., 1998; Walters and Blendy, 2001). CBP is known to associate with phosphorylated CREB to mediate targeted gene activation (Chrivia et al., 1993; Xu et al., 2007). In this study, we found that acute cocaine leads to the recruitment of CBP and increases histone acetylation at the c-fos promoter to regulate c-FOS expression. The absence of CBP blunts c-fos expression, a known target of CREB and CBP (Barrett et al., 2011). These data indicate that CBP activity is critical for CREB-mediated gene expression in response to acute cocaine exposure. The observed lack of c-fos induction in wild-type mice following chronic cocaine treatment is consistent with reports that chronic psychostimulant exposure fails to induce expression of immediate early genes (IEGs) and may even reduce their expression (Bhat et al., 1992; Hope et al., 1992; Steiner and Gerfen, 1993; Couceyro et al., 1994; Ennulat et al., 1994; Cole et al., 1995; Konradi et al., 1996; Moratalla et al., 1996; Renthal et al., 2008; McCoy et al., 2011). The current study shows that following chronic cocaine treatment, CBP occupancy and acetylation at the c-fos promoter is reduced in comparison to acute cocaine treatment. The mechanisms that repress IEG expression after chronic drug exposure remain unclear, as the residual occupancy of CBP at the promoter of c-fos suggests that other mechanisms are working in concert in the desensitization of IEG expression. Renthal et al. (2008) proposed that the blunted c-fos expression following chronic drug treatment is mediated by delta FosB, which acts by recruiting corepressors to the promoter of c-fos.

It was unexpected that chronic cocaine exposure could result in increased c-fos levels in mice lacking CBP, since its initial induction has been shown to depend on CBP activity (Chawla et al. 1998; Barrett et al. 2011; Chrivia et al. 1993; also see Fig. 3, Acute). One possibility is that deletion of CBP activated nonspecific compensatory mechanisms that led to the rampant induction of c-fos. Another possibility is that CBP is part of a critical mechanism regulating the desensitization of c-fos in response to chronic co- 
caine. In either case, our studies indicate that CBP is part of a pivotal mechanism maintaining drug-induced molecular changes. It will be important to determine what leads to this deregulation of c-fos in the absence of CBP, as it may be pointing to a key mechanism of cocaine action.

Numerous studies have shown that the behavioral effects induced by drugs of abuse are enhanced or diminished by increases or decreases in histone acetylation, respectively (Kumar et al., 2005; Levine et al., 2005; Kalda et al., 2007; Renthal et al., 2007; Romieu et al., 2008; Schroeder et al., 2008; Shen et al., 2008; Sun et al., 2008). Only one study to date attempted to investigate the HATs regulating histone acetylation contributing to druginduced behaviors. Levine et al. (2005) found that CBP haploinsufficient mice were less sensitive to the locomotor activating effects of cocaine. In that strain, CBP activity is reduced in all brain regions throughout development (Tanaka et al., 1997), making it difficult to attribute the effects of CBP to specific brain regions. Furthermore, these mice have severe developmental problems such as missing digits, ribs, and other skeletal abnormalities (Tanaka et al., 1997) that can lead to experimental confounds. In this study, we used AAV-Cre to generate a complete CBP knock-out restricted to the nucleus accumbens of adult mice. We found that loss of CBP and the resulting decrease in histone acetylation in the nucleus accumbens correlate with reduced cocaine sensitivity. This finding provides critical insight into the brain region where CBP is exerting its effect. Importantly, we also showed that lack of CBP in the nucleus accumbens impaired cocaine-associated memory. Together, this designates an important role for CBP within the nucleus accumbens in the behavioral responses to cocaine.

In summary, this study is the first to identify a definitive role for CBP in the nucleus accumbens. We examined the effects of a complete knock-out of CBP in the nucleus accumbens of adult mice, which has not been possible to investigate before. This study showed that CBP activity is critical in regulating histone modifications and gene expression in response to cocaine and that CBP serves an important function in the development of pervasive drug-associated memories that may contribute to drug addiction. Further studies will be pivotal in exploring the array genes regulated by $\mathrm{CBP}$ in response to cocaine.

\section{References}

Alarcón JM, Malleret G, Touzani K, Vronskaya S, Ishii S, Kandel ER, Barco A (2004) Chromatin acetylation, memory, and LTP are impaired in $\mathrm{CBP}+/-$ mice: a model for the cognitive deficit in Rubinstein-Taybi syndrome and its amelioration. Neuron 42:947-959.

Barrett RM, Wood MA (2008) Beyond transcription factors: the role of chromatin modifying enzymes in regulating transcription required for memory. Learn Mem 15:460-467.

Barrett RM, Malvaez M, Kramar E, Matheos DP, Arrizon A, Cabrera SM, Lynch G, Greene RW, Wood MA (2011) Hippocampal focal knock-out of CBP affects specific histone modifications, long-term potentiation, and long-term memory. Neuropsychopharmacology 36:1545-1556.

Bertran-Gonzalez J, Bosch C, Maroteaux M, Matamales M, Hervé D, Valjent E, Girault JA (2008) Opposing patterns of signaling activation in dopamine D1 and D2 receptor-expressing striatal neurons in response to cocaine and haloperidol. J Neurosci 28:5671-5685.

Bhat RV, Cole AJ, Baraban JM (1992) Chronic cocaine treatment suppresses basal expression of zif268 in rat forebrain: in situ hybridization studies. J Pharmacol Exp Ther 263:343-349.

Bibb JA, Chen J, Taylor JR, Svenningsson P, Nishi A, Snyder GL, Yan Z, Sagawa ZK, Ouimet CC, Nairn AC, Nestler EJ, Greengard P (2001) Effects of chronic exposure to cocaine are regulated by the neuronal protein Cdk5. Nature 410:376-380.

Burger C, Gorbatyuk OS, Velardo MJ, Peden CS, Williams P, Zolotukhin S, Reier PJ, Mandel RJ, Muzyczka N (2004) Recombinant AAV viral vec- tors pseudotyped with viral capsids from serotypes 1,2, and 5 display differential efficiency and cell tropism after delivery to different regions of the central nervous system. Mol Ther 10:302-317.

Carlezon WA Jr, Thome J, Olson VG, Lane-Ladd SB, Brodkin ES, Hiroi N, Duman RS, Neve RL, Nestler EJ (1998) Regulation of cocaine reward by CREB. Science 282:2272-2275.

Chrivia JC, Kwok RP, Lamb N, Hagiwara M, Montminy MR, Goodman RH (1993) Phosphorylated CREB binds specifically to the nuclear protein CBP. Nature 365:855-859.

Cole RL, Konradi C, Douglass J, Hyman SE (1995) Neuronal adaptation to amphetamine and dopamine: molecular mechanisms of prodynorphin gene regulation in rat striatum. Neuron 14:813-823.

Couceyro P, Pollock KM, Drews K, Douglass J (1994) Cocaine differentially regulates activator protein-1 mRNA levels and DNA-binding complexes in the rat striatum and cerebellum. Mol Pharmacol 46:667-676.

Daunais JB, Roberts DC, McGinty JF (1993) Cocaine self-administration increases preprodynorphin, but not c-fos, mRNA in rat striatum. Neuroreport 4:543-546.

Di Chiara G, Imperato A (1988) Drugs abused by humans preferentially increase synaptic dopamine concentrations in the mesolimbic system of freely moving rats. Proc Natl Acad Sci U S A 85:5274-5278.

Dion MF, Altschuler SJ, Wu LF, Rando OJ (2005) Genomic characterization reveals a simple histone H4 acetylation code. Proc Natl Acad Sci U S A 102:5501-5506.

Ennulat DJ, Babb S, Cohen BM (1994) Persistent reduction of immediate early gene mRNA in rat forebrain following single or multiple doses of cocaine. Brain Res Mol Brain Res 26:106-112.

Graybiel AM, Moratalla R, Robertson HA (1990) Amphetamine and cocaine induce drug-specific activation of the c-fos gene in striosome-matrix compartments and limbic subdivisions of the striatum. Proc Natl Acad Sci U S A 87:6912-6916.

Gross NB, Duncker PC, Marshall JF (2011) Striatal dopamine D1 and D2 receptors: widespread influences on methamphetamine-induced dopamine and serotonin neurotoxicity. Synapse 65:1144-1155.

Hope B, Kosofsky B, Hyman SE, Nestler EJ (1992) Regulation of immediate early gene expression and AP-1 binding in the rat nucleus accumbens by chronic cocaine. Proc Natl Acad Sci U S A 89:5764-5768.

Hope BT, Nye HE, Kelz MB, Self DW, Iadarola MJ, Nakabeppu Y, Duman RS, Nestler EJ (1994) Induction of a long-lasting AP-1 complex composed of altered Fos-like proteins in brain by chronic cocaine and other chronic treatments. Neuron 13:1235-1244.

Hyman SE, Malenka RC (2001) Addiction and the brain: the neurobiology of compulsion and its persistence. Nat Rev Neurosci 2:695-703.

Hyman SE, Malenka RC, Nestler EJ (2006) Neural mechanisms of addiction: the role of reward-related learning and memory. Annu Rev Neurosci 29:565-598.

Kalda A, Heidmets LT, Shen HY, Zharkovsky A, Chen JF (2007) Histone deacetylase inhibitors modulates the induction and expression of amphetamine-induced behavioral sensitization partially through an associated learning of the environment in mice. Behav Brain Res 181:76-84.

Kang-Decker N, Tong C, Boussouar F, Baker DJ, Xu W, Leontovich AA, Taylor WR, Brindle PK, van Deursen JM (2004) Loss of CBP causes T cell lymphomagenesis in synergy with p27Kip1 insufficiency. Cancer Cell 5:177-189.

Kleff S, Andrulis ED, Anderson CW, Sternglanz R (1995) Identification of a gene encoding a yeast histone $\mathrm{H} 4$ acetyltransferase. J Biol Chem 270:24674-24677.

Konradi C, Cole RL, Heckers S, Hyman SE (1994) Amphetamine regulates gene expression in rat striatum via transcription factor CREB. J Neurosci 14:5623-5634.

Konradi C, Leveque JC, Hyman SE (1996) Amphetamine and dopamineinduced immediate early gene expression in striatal neurons depends on postsynaptic NMDA receptors and calcium. J Neurosci 16:4231-4239.

Kouzarides T (2007) Chromatin modifications and their function. Cell 128:693-705.

Kumar A, Choi KH, Renthal W, Tsankova NM, Theobald DE, Truong HT, Russo SJ, Laplant Q, Sasaki TS, Whistler KN, Neve RL, Self DW, Nestler EJ (2005) Chromatin remodeling is a key mechanism underlying cocaineinduced plasticity in striatum. Neuron 48:303-314.

Levine AA, Guan Z, Barco A, Xu S, Kandel ER, Schwartz JH (2005) CREBbinding protein controls response to cocaine by acetylating histones at the 
fosB promoter in the mouse striatum. Proc Natl Acad Sci U S A 102:19186-19191.

Malvaez M, Sanchis-Segura C, Vo D, Lattal KM, Wood MA (2010) Modulation of chromatin modification facilitates extinction of cocaine-induced conditioned place preference. Biol Psychiatry 67:36-43.

Maze I, Covington HE 3rd, Dietz DM, LaPlant Q, Renthal W, Russo SJ, Mechanic M, Mouzon E, Neve RL, Haggarty SJ, Ren Y, Sampath SC, Hurd YL, Greengard P, Tarakhovsky A, Schaefer A, Nestler EJ (2010) Essential role of the histone methyltransferase G9a in cocaine-induced plasticity. Science 327:213-216.

McClung CA, Nestler EJ (2003) Regulation of gene expression and cocaine reward by CREB and DeltaFosB. Nat Neurosci 6:1208-1215.

McClung CA, Nestler EJ (2008) Neuroplasticity mediated by altered gene expression. Neuropsychopharmacology 33:3-17.

McCoy MT, Jayanthi S, Wulu JA, Beauvais G, Ladenheim B, Martin TA, Krasnova IN, Hodges AB, Cadet JL (2011) Chronic methamphetamine exposure suppresses the striatal expression of members of multiple families of immediate early genes (IEGs) in the rat: normalization by an acute methamphetamine injection. Psychopharmacology (Berl) 215:353-365.

McQuown SC, Wood MA (2010) Epigenetic regulation in substance use disorders. Curr Psychiatry Rep 12:145-153.

McQuown SC, Barrett RM, Matheos DP, Post RJ, Rogge GA, Alenghat T, Mullican SE, Jones S, Rusche JR, Lazar MA, Wood MA (2011) HDAC3 is a critical negative regulator of long-term memory formation. J Neurosci 31:764-774.

Miller CA, Marshall JF (2005) Altered Fos expression in neural pathways underlying cue-elicited drug seeking in the rat. Eur J Neurosci 21:1385-1393.

Moratalla R, Robertson HA, Graybiel AM (1992) Dynamic regulation of NGFI-A (zif268, egr1) gene expression in the striatum. J Neurosci 12:2609-2622.

Moratalla R, Elibol B, Vallejo M, Graybiel AM (1996) Network-level changes in expression of inducible Fos-Jun proteins in the striatum during chronic cocaine treatment and withdrawal. Neuron 17:147-156.

Myers FA, Chong W, Evans DR, Thorne AW, Crane-Robinson C (2003) Acetylation of histone $\mathrm{H} 2 \mathrm{~B}$ mirrors that of $\mathrm{H} 4$ and $\mathrm{H} 3$ at the chicken beta-globin locus but not at housekeeping genes. J Biol Chem 278:36315-36322.

Nestler EJ (2001) Molecular basis of long-term plasticity underlying addiction. Nat Rev Neurosci 2:119-128.

Nestler EJ, Bergson CM, Gultart X, Hope BT (1993) Regulation of neural gene expression in opiate and cocaine addiction. NIDA Res Monogr 125:92-116.

Ogryzko VV, Schiltz RL, Russanova V, Howard BH, Nakatani Y (1996) The transcriptional coactivators $\mathrm{p} 300$ and CBP are histone acetyltransferases. Cell 87:953-959.

Pandey SC, Ugale R, Zhang H, Tang L, Prakash A (2008) Brain chromatin remodeling: a novel mechanism of alcoholism. J Neurosci 28:3729-3737.

Pfaffl MW (2001) A new mathematical model for relative quantification in real-time RT-PCR. Nucleic Acids Res 29:e45.

Pfaffl MW, Georgieva TM, Georgiev IP, Ontsouka E, Hageleit M, Blum JW (2002) Real-time RT-PCR quantification of insulin-like growth factor (IGF)-1, IGF-1 receptor, IGF-2, IGF-2 receptor, insulin receptor, growth hormone receptor, IGF-binding proteins 1,2 and 3 in the bovine species. Domest Anim Endocrinol 22:91-102.

Pham J, Cabrera SM, Sanchis-Segura C, Wood MA (2009) Automated scoring of fear-related behavior using EthoVision software. J Neurosci Methods 178:323-326.

Renthal W, Nestler EJ (2008) Epigenetic mechanisms in drug addiction. Trends Mol Med 14:341-350.

Renthal W, Maze I, Krishnan V, Covington HE 3rd, Xiao G, Kumar A, Russo
SJ, Graham A, Tsankova N, Kippin TE, Kerstetter KA, Neve RL, Haggarty SJ, McKinsey TA, Bassel-Duby R, Olson EN, Nestler EJ (2007) Histone deacetylase 5 epigenetically controls behavioral adaptations to chronic emotional stimuli. Neuron 56:517-529.

Renthal W, Carle TL, Maze I, Covington HE 3rd, Truong HT, Alibhai I, Kumar A, Montgomery RL, Olson EN, Nestler EJ (2008) Delta FosB mediates epigenetic desensitization of the c-fos gene after chronic amphetamine exposure. J Neurosci 28:7344-7349.

Romieu P, Host L, Gobaille S, Sandner G, Aunis D, Zwiller J (2008) Histone deacetylase inhibitors decrease cocaine but not sucrose self-administration in rats. J Neurosci 28:9342-9348.

Scammell TE, Arrigoni E, Thompson MA, Ronan PJ, Saper CB, Greene RW (2003) Focal deletion of the adenosine A1 receptor in adult mice using an adeno-associated viral vector. J Neurosci 23:5762-5770.

Schroeder FA, Penta KL, Matevossian A, Jones SR, Konradi C, Tapper AR, Akbarian S (2008) Drug-induced activation of dopamine $\mathrm{D}(1)$ receptor signaling and inhibition of class I/II histone deacetylase induce chromatin remodeling in reward circuitry and modulate cocaine-related behaviors. Neuropsychopharmacology 33:2981-2992.

Self DW, Nestler EJ (1995) Molecular mechanisms of drug reinforcement and addiction. Annu Rev Neurosci 18:463-495.

Shen HY, Kalda A, Yu L, Ferrara J, Zhu J, Chen JF (2008) Additive effects of histone deacetylase inhibitors and amphetamine on histone $\mathrm{H} 4$ acetylation, cAMP responsive element binding protein phosphorylation and DeltaFosB expression in the striatum and locomotor sensitization in mice. Neuroscience 157:644-655.

Steiner H, Gerfen CR (1993) Cocaine-induced c-fos messenger RNA is inversely related to dynorphin expression in striatum. J Neurosci 13:5066-5081.

Sun J, Wang L, Jiang B, Hui B, Lv Z, Ma L (2008) The effects of sodium butyrate, an inhibitor of histone deacetylase, on the cocaine- and sucrosemaintained self-administration in rats. Neurosci Lett 441:72-76.

Tanaka Y, Naruse I, Maekawa T, Masuya H, Shiroishi T, Ishii S (1997) Abnormal skeletal patterning in embryos lacking a single Cbp allele: a partial similarity with Rubinstein-Taybi syndrome. Proc Natl Acad Sci U S A 94:10215-10220.

Valor LM, Pulopulos MM, Jimenez-Minchan M, Olivares R, Lutz B, Barco A (2011) Ablation of CBP in forebrain principal neurons causes modest memory and transcriptional defects and a dramatic reduction of histone acetylation but does not affect cell viability. J Neurosci 31:1652-1663.

Vecsey CG, Hawk JD, Lattal KM, Stein JM, Fabian SA, Attner MA, Cabrera SM, McDonough CB, Brindle PK, Abel T, Wood MA (2007) Histone deacetylase inhibitors enhance memory and synaptic plasticity via $\mathrm{CREB}$ : CBP-dependent transcriptional activation. J Neurosci 27:6128-6140.

Walters CL, Blendy JA (2001) Different requirements for cAMP response element binding protein in positive and negative reinforcing properties of drugs of abuse. J Neurosci 21:9438-9444.

Wang JQ, McGinty JF (1995) Dose-dependent alteration in zif/268 and preprodynorphin mRNA expression induced by amphetamine or methamphetamine in rat forebrain. J Pharmacol Exp Ther 273:909-917.

Winstanley CA, Green TA, Theobald DE, Renthal W, LaPlant Q, DiLeone RJ, Chakravarty S, Nestler EJ (2009) DeltaFosB induction in orbitofrontal cortex potentiates locomotor sensitization despite attenuating the cognitive dysfunction caused by cocaine. Pharmacol Biochem Behav 93:278-284.

Wise RA (1996) Neurobiology of addiction. Curr Opin Neurobiol 6:243-251.

Xu W, Kasper LH, Lerach S, Jeevan T, Brindle PK (2007) Individual CREBtarget genes dictate usage of distinct cAMP-responsive coactivation mechanisms. EMBO J 26:2890-2903. 